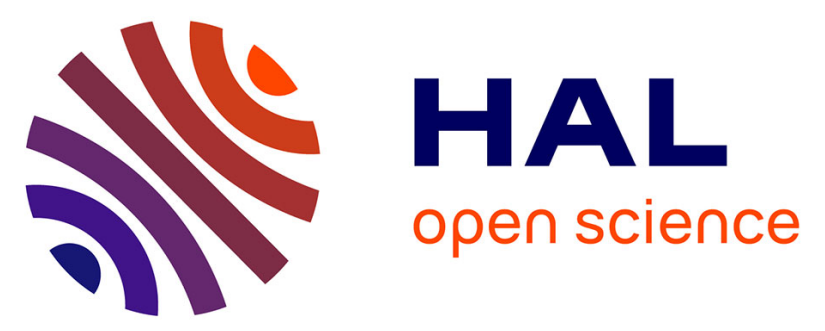

\title{
Peptide mapping of polypeptides separated by two-dimensional electrophoresis: Protease digestion directly on the two-dimensional gel followed by electrophoresis in reverse direction
}

\author{
M. Zivy, Fabienne Granier
}

\section{To cite this version:}

M. Zivy, Fabienne Granier. Peptide mapping of polypeptides separated by two-dimensional electrophoresis: Protease digestion directly on the two-dimensional gel followed by electrophoresis in reverse direction. Electrophoresis, 1988, 9 (7), pp.339-343. 10.1002/elps.1150090710 . hal-02719515

\author{
HAL Id: hal-02719515 \\ https://hal.inrae.fr/hal-02719515
}

Submitted on 1 Jun 2020

HAL is a multi-disciplinary open access archive for the deposit and dissemination of scientific research documents, whether they are published or not. The documents may come from teaching and research institutions in France or abroad, or from public or private research centers.
L'archive ouverte pluridisciplinaire $\mathbf{H A L}$, est destinée au dépôt et à la diffusion de documents scientifiques de niveau recherche, publiés ou non, émanant des établissements d'enseignement et de recherche français ou étrangers, des laboratoires publics ou privés. 
[18] Goldberg. R. L. and Fuller. G. C.. Anal. Biochem. 1978.90.69-80.

[19] Chen-Kiang, S., Stein, S. and Udenfriend, S., Anal. Biochem. 1979, $95,122-126$.

[20] Falk, B. W. and Elliot, C., Anal. Biochem. 1985, 144, 537-541.

[21] Stephens, R. E., Anal. Biochem. 1975, 65, 369-379.

[22] Tijssen, P. and Kurstak, E., Anal. Biochem. 1979, 99, 97-104.

[23] Tsugita, A., Sasada, S., van den Broek, R. and Scheffler, J. J., Eur.J. Biochem. 1982, 124, 171-176.

[24] Horowitz, P. M. and Bowman, S., Anal. Biochem. 1987, 165, $430-434$.

[25] Nerenberg, S. T., Ganger, C. and De Marco, L., Anal.Biochem. 1971, $43,564-574$.

[26] Hartman, B. K. and Udenfriend, S., Anal. Biochem. 1969, 30, $391-394$.

[27] Daban, J.-R. and Aragay, A. M., Anal. Biochem. 1984, 138, 223-228.
[28] Pina, B., Aragay, A. M., Suau, P. and Daban, J.-R., Anal. Biochem. $1985,146,431-433$.

[29] Aragay, A. M., Diaz. P. and Daban, J.-R., Electrophoresis 1985, 6, $527-531$.

[30] Weigele, M., De Bernardo, S., Leimgruber, W., Cleeland, R. and Grunberg, E., Biochem. Biophys. Res. Comm. 1973, 54, 899-906.

[31] Bradford, M. M., Anal. Biochem. 1976, 72, 248-254.

[32] Scopes, R. K., Anal. Biochem. 1974, 59, 277-282.

[33] Laemmli, U. K., Nature 1970, 227, 680-685.

[34] O'Farrell, P. H., J. Biol. Chem. 1975, 250, 4007-4021.

[35] Anderson, N. G. and Anderson, N. L., Anal. Biochem. 1978, 85, 331-341.

[36] Anderson, N. G. and Anderson, N. L., Anal. Biochem. 1978, 85, 341-354.

[37] Neville, D. M., J. Biol. Chem. 1971, 246, 6328-6334.

[38] Lane, L. C., Ann. Biochem. 1978, 86, 655-664.
Michel Zivy

Fabienne Granier

Laboratoire de Génétique des

Systèmes Végétaux,

CNRS-INRA-UPS, Gif-sur-Yvette

\section{Peptide mapping of polypeptides separated by two- dimensional electrophoresis: Protease digestion directly on the two-dimensional gel followed by electrophoresis in reverse direction}

\begin{abstract}
A method is described which allows to reveal simultaneously the proteolytic patterns of numerous polypeptides separated by two-dimensional electrophoresis. After two-dimensional electrophoresis, the gels were dipped successively in buffers for preequilibration, protease digestion, and reequilibration. They were then returned to the electrophoresis tank, and electrophoresis was continued for a short time. After silver staining, digestion products appeared, lined up behind the original polypeptide spots. The method allows proteolytic patterns of numerous polypeptides to be viasualized simply and quickly. Among proteins of wheat leaves, 31 groups of related polypeptides were found according to the similarity of their proteolytic patterns.
\end{abstract}

\section{Introduction}

Some of the spots revealed by two-dimensional polyacrylamide gel electrophoresis (2D-PAGE) [1] of complex biological samples can correspond to related polypeptides: for example, two spots can correspond to the products of allelic genes or of homoeoallelic genes if the studied species is a polyploid, or to the products of a single gene differing by posttranslational modifications [2]. For the interpretation of experiments using 2D-PAGE, knowledge of the relations between the individual polypeptides can be useful. Structural relations between several polypeptides may be detected by comparing patterns following proteolytic digestion. However, it would be too time-consuming to do it for numerous polypeptides with the techniques currently available [3-5]

\section{Correspondence: Michel Zivy, Laboratoire de Génétique des Systèmes} Végétaux, La Ferme du Moulon, F-91190 Gif sur Yvette, France

Abbreviations: 2D, two-dimensional; IEF, isoelectric focusing; PAGE, polyacrylamide gel electrophoresis; SDS, sodium dodecyl sulfate which are based on elution of proteins from 2D gels prior to digestion. We have developed a technique that allows the observation of the proteolytic patterns directly on the $2 \mathrm{D}$ gel.

\section{Materials and methods}

\subsection{Protein extraction}

Proteins of young leaves and etiolated seedlings of the common wheat variety "Chinese Spring" were extracted as in [6], except that the protein load on the isoelectric focusing (IEF) gel was doubled.

\subsection{D-PAGE}

2D-PAGE was performed according to [7]. IEF was performed for $40000 \mathrm{Vh}$ in $24 \mathrm{~cm}$ long rod gels (inner diameter 1 $\mathrm{mm})$. The carrier ampholyte concentration in the gel was $4 \%$ (3 parts Pharmalyte $\mathrm{pH}$ 5-8, 1 part Pharmalyte $\mathrm{pH}$ 5-6). The gels were equilibrated for $15 \mathrm{~min}$ in $62.5 \mathrm{~mm}$ Tris- $\mathrm{HCl}, \mathrm{pH} 8.8$, 
$2.3 \%$ sodium dodecyl sulfate (SDS), $10 \%$ sucrose. The second-dimensional separation was performed on $215 \times 240 \times$ $1 \mathrm{~mm}$ slab gels backed to GelBond PAG film. Several gels (11\% T, $2.65 \%$ C, 0.5 M Tris- $\mathrm{HCl}, \mathrm{pH} 8.8,0.15 \% \mathrm{SDS}, 1 \%$ sucrose) were simultaneously run in a DALT tank for 20 gels [8], and simultaneously silver stained in the apparatus described in [9]. The silver staining method was performed according to [10], with the modifications described in [11].

\subsection{Proteolysis method}

The "standard" procedure will be described below and any modifications will refer to this one. All steps of equilibration were done under gentle agitation, with $500 \mathrm{~mL}$ per gel. The procedure was as follows: 1) 2D-PAGE was performed as described in Section 2.2.2) Gel equilibration for proteolysis: the $2 \mathrm{D}$ gels were removed from the apparatus and dipped in a $0.2 \mathrm{M}$ Tris- $\mathrm{HCl}, \mathrm{pH} 7$, buffer for $20 \mathrm{~min}$ (two baths of $10 \mathrm{~min}$ ). 3) Proteolysis: the gels were transferred to another bath of the same buffer containing additionally $0.18 \mathrm{~nm}(50 \mu \mathrm{g} / 100 \mathrm{~mL})$ ficin (Sigma Product No. F 6008) for $30 \mathrm{~min}$. The temperature was adjusted to $20^{\circ} \mathrm{C}$ before incubation. 4) Gel equilibration for electrophoresis: the gels were dipped in the "tank buffer" (25 mM Tris, $0.2 \mathrm{M}$ glycine, $0.1 \% \mathrm{SDS}$ ) for $15 \mathrm{~min}$ (first bath for $5 \mathrm{~min}$ and second bath for $10 \mathrm{~min}$ ). 5) Continued electrophoresis: the gels were returned to the apparatus. Clamps were used to prevent inclusion of air bubbles or tank buffer. The gels were positioned with the top oriented downwards and electrophoresis restarted in the opposite direction. The presence of GelBond made the gel handling easier, and was helpful for positioning them correctly. Electrophoresis was performed for $1 \mathrm{~h}$ at a constant current of $0.7 \mathrm{~A}$.

\section{Results and discussion}

\subsection{Restart of migration and protease activity}

The best buffer conditions for protease activity and for the restart of migration were different. Preliminary experiments showed that the tank buffer was optimal for restarting migration. Figs. $1 \mathrm{a}$ and $\mathrm{l} b$ show a gel run under normal conditions and a control gel (standard method without protease at step 3 ).
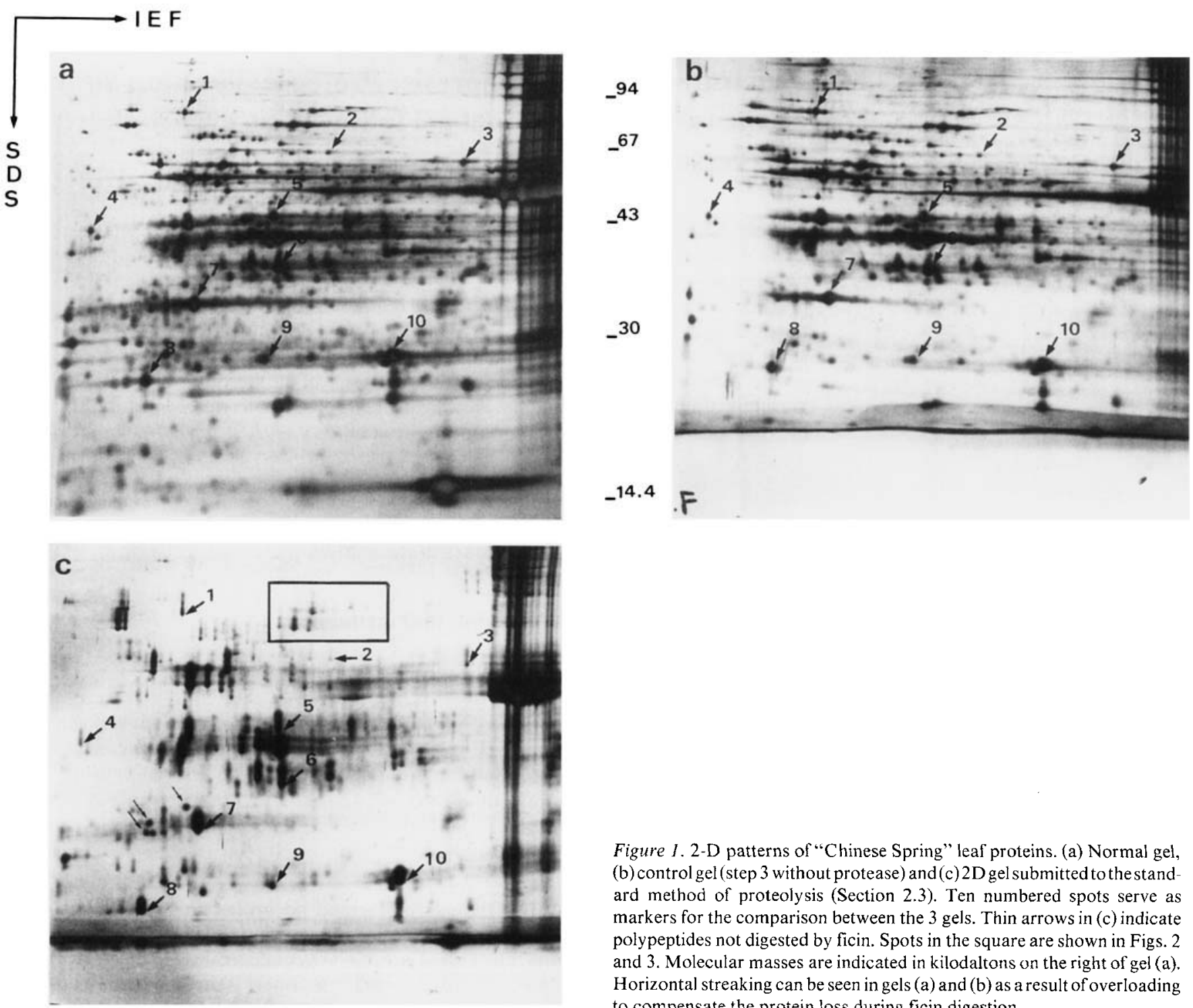

Figure 1. 2-D patterns of "Chinese Spring" leaf proteins. (a) Normal gel, (b) control gel (step 3 without protease) and (c) $2 \mathrm{D}$ gel submitted to the stand ard method of proteolysis (Section 2.3). Ten numbered spots serve as markers for the comparison between the 3 gels. Thin arrows in (c) indicate polypeptides not digested by ficin. Spots in the square are shown in Figs. 2 and 3. Molecular masses are indicated in kilodaltons on the right of gel (a). Horizontal streaking can be seen in gels (a) and (b) as a result of overloading to compensate the protein loss during ficin digestion. 
No vertical streaking was observed on the latter, which shows that the restart of the migration was good. By contrast, if migration was restarted in the same direction as before protease treatment an additional front appeared (see Fig. 3) proving that equilibration step 4 was not adequate for complete reequilibration with tank buffer. In a number of experiments we have tried to find a buffer allowing good ficin activity and compatibility with good migration, restarting electrophoresis. Optimal conditions for ficin activity are $\mathrm{pH} 7$ and $37^{\circ} \mathrm{C}$, but already $20^{\circ} \mathrm{C}$ proved adequate. A high molarity of Tris buffer, $\mathrm{pH} 7$, was necessary because at low molarity (25 mM), migration on restarting electrophoresis was inferior despite equilibration step 4 . Other buffers were also tested and, as expected, replacing the buffer of steps 2 and 3 by the tank buffer resulted in a good restart of migration (without an additional front), but ficin activity was lowered considerably. Incubation in the tank buffer, adjusted to $\mathrm{pH} 7$ with $\mathrm{HCl}$, resulted in a relatively good restart of migration, but ficin activity was still reduced, although less than with regular tank buffer. The tank buffer without SDS, either adjusted to $\mathrm{pH} 7$ or nonadjusted, resulted in a bad restart of migration. Best results were obtained with the two steps of equilibration (steps 2 and 4). If either step 2 or step 4 were omitted the results were acceptable but with respectively lower activity of the protease and an impaired restart of migration.

Other proteases were tested: $\alpha$-chymotrypsin (Sigma C 7762; buffers of steps 2 and 3: $0.2 \mathrm{M}$ Tris- $\mathrm{HCl}, \mathrm{pH} 8.8$ ), papain (Sigma P 4762; $0.022 \mathrm{M} \mathrm{KH}_{2} \mathrm{PO}_{4}, 0.048 \mathrm{M} \mathrm{Na}_{2} \mathrm{HPO}_{4}, \mathrm{pH}$ 7.2), Streptomyces griseus protease (Sigma P 0652; glycine, $0.051 \mathrm{M} \mathrm{NaCl}, \mathrm{NaOH}, \mathrm{pH} 11)$, Staphylococcus aureus V8 protease (Sigma P 8400;0.2 M Tris-HCl, pH 7.5), and elastase (Sigma E 1250;0.2 M Tris-HCl, pH 8.8). For papain, elastase, and Streptomyces griseus protease, the restart of migration was bad, and it was impossible to assess whether digestion had occurred; other buffers in steps 2 and 3 have yet to be tested. With Staphylococcus aureus protease, no digestion products were observed with enzyme concentrations up to $150 \mu \mathrm{g} / 100 \mathrm{~mL}$; restart of migration was good. Only faint proteolytic patterns were observed even at high concentration of $\alpha$-chymotrypsin $(200 \mu \mathrm{g} / 100 \mathrm{~mL})$.

Fig. 1c shows a gel treated by the standard method. On restarting electrophoresis in the opposite direction to the original separation, the proteolytic products of each polypeptide were observed above the original spot. Of the 450 spots visible in regular gels, about 250 were still visible after proteolysis. The absence of numerous spots, and the reduced intensity of most of them, was mainly due to protease activity since, otherwise, almost all spots retained approximately their original intensity in the control gels (Fig. 1b). About $75 \%$ of these 250 spots showed a pattern of proteolysis (even if fuzzy). Most of the remaining $25 \%$ were also digested, since their intensity decreased markedly, but they were too small for the digestion products to be seen. Nevertheless, few polypeptides were clearly not digested by ficin: their intensity was similar to that in the control gel, and there were no traces of digestion products above them. Some relatively large spots not degraded by ficin are shown in Fig. 1c.

In addition to the selection of protease, several parameters can be changed to improve the proteolytic patterns or their reproducibility. At higher protease concentration the number of digestion products is increased (Fig. 2), but at levels that were too high, a background appeared, visible e. $g$. for ficin at a
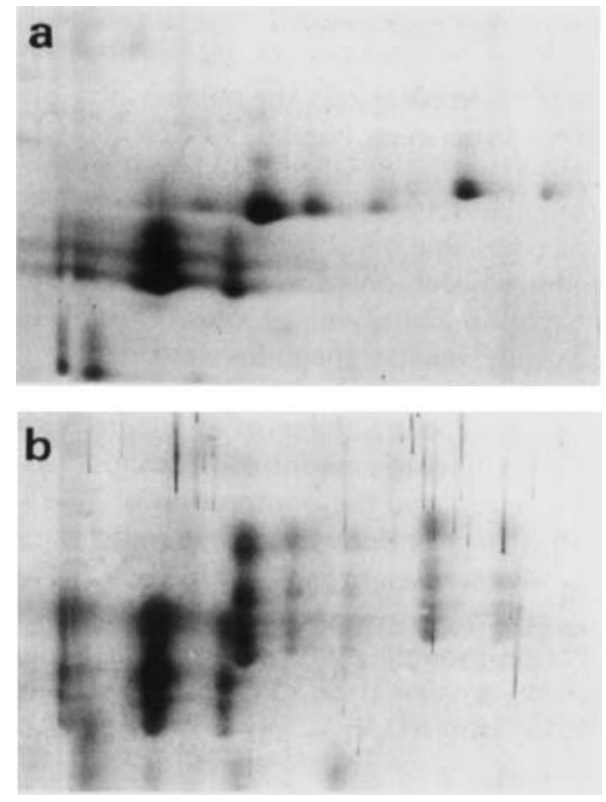

Figure 2. Effect of ficin concentration on digestion. (a) $25 \mu \mathrm{g} / 100 \mathrm{~mL}$; (b) $100 \mu \mathrm{g} / 100 \mathrm{~mL}$.

concentration of $500 \mu \mathrm{g} / 100 \mathrm{~mL}$. When the patterns of several spots are superimposed, the migration of step 5 can be performed in another direction, although a second front appears when the direction is not reversed (Fig. 3). The duration of the second migration can be optimized for specific spots. The pattern of some spots can never be correctly observed, especially in the case of high density of relatively small spots. In such a case it may be preferable to use other protein extracts from other organs or subcellular fractions with a resultant decrease of spots in the vicinity of spots of interest.
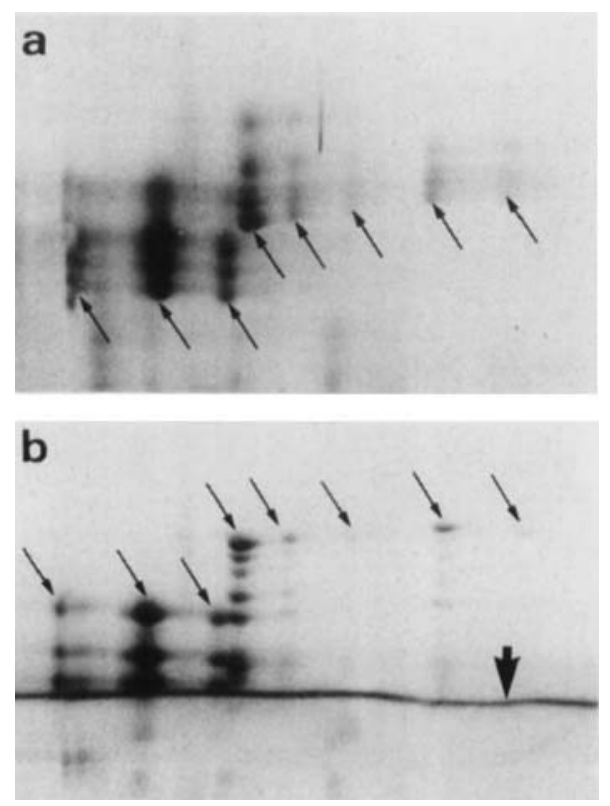

Figure 3. Changing the direction on restarting electrophoresis. (a) Electrophoresis restarted in the direction opposite to the original separation (stan dard method); (b) restarted in the same direction. Small arrows show the original polypeptide spots. The large arrow shows the second migration front. 


\subsection{Comparison of proteolytic patterns}

With the standard method (Section 2.3), the number of spots per proteolytic pattern was between 1 and 6 . Two proteolytic patterns were considered as similar when they had the same number of spots, with similar relative positions and intensities, and when this was reproducible on at least 3 gels. With the silver staining method used here, only few spots had specific colors but this was useful in identifying profiles. Thirty-one groups of "Chinese Spring" leaf polypeptides were identified according to the similarity of their proteolytic patterns (Fig. 4) with seventy-six spots grouped. Similar experiments with etiolated seedlings allowed the confirmation of 17 groups (proteins present in both tissues) and the observation of 7 new groups (proteins either absent or barely visible in patterns of leaf proteins). By studying two organs, 100 spots were assigned to similarity groups. However, this does not represent the total information brought by the method, since the absence of similarity between two given spots is also valuable (and actually more easily proved).

All groups contained 2-5 polypeptides. As "Chinese Spring" is a homozygous line of a hexaploid species, homoeoallelic products were expected to give rise to groups of 1 to 3 spots in the absence of posttranslational modifications [12]. Thus, it is likely that at least the groups of more than 3 polypeptides contain products of posttranslational modifications. In general, this technique gives no information by itself on the causes of the similarities observed, but it can be used to verify hypotheses deduced from other experiments. For example, spots $\mathrm{C} 1$ and $\mathrm{C} 2$ were suspected to correspond to two products of the same cytoplasmic gene because of their similar behavior according to the cytoplasmic genome [13] (the third spot of this group was not considered in this study because it was not reproducible enough). The similarity of their digestion profiles observed by this technique reinforced this hypothesis. In this case, their structural similarity was finally proved by immunological techniques: they correspond to different forms of the $\beta$ subunit of the chloroplastic ATP synthase.

\section{Concluding remarks}

Peptide mapping of proteins, digested by proteases directly in $2 \mathrm{D}$ gels can quickly provide valuable information on the relationships between polypeptides. It can be used, when additional spots are observed after protein purification, to test whether they are contaminants or modifications of the same protein. Another application is the comparison between products of in vitro translation and products of in vivo synthesis. It can also be particularly useful in phylogenetic studies for the comparison between 2D patterns of different species.

Received February 25, 1988

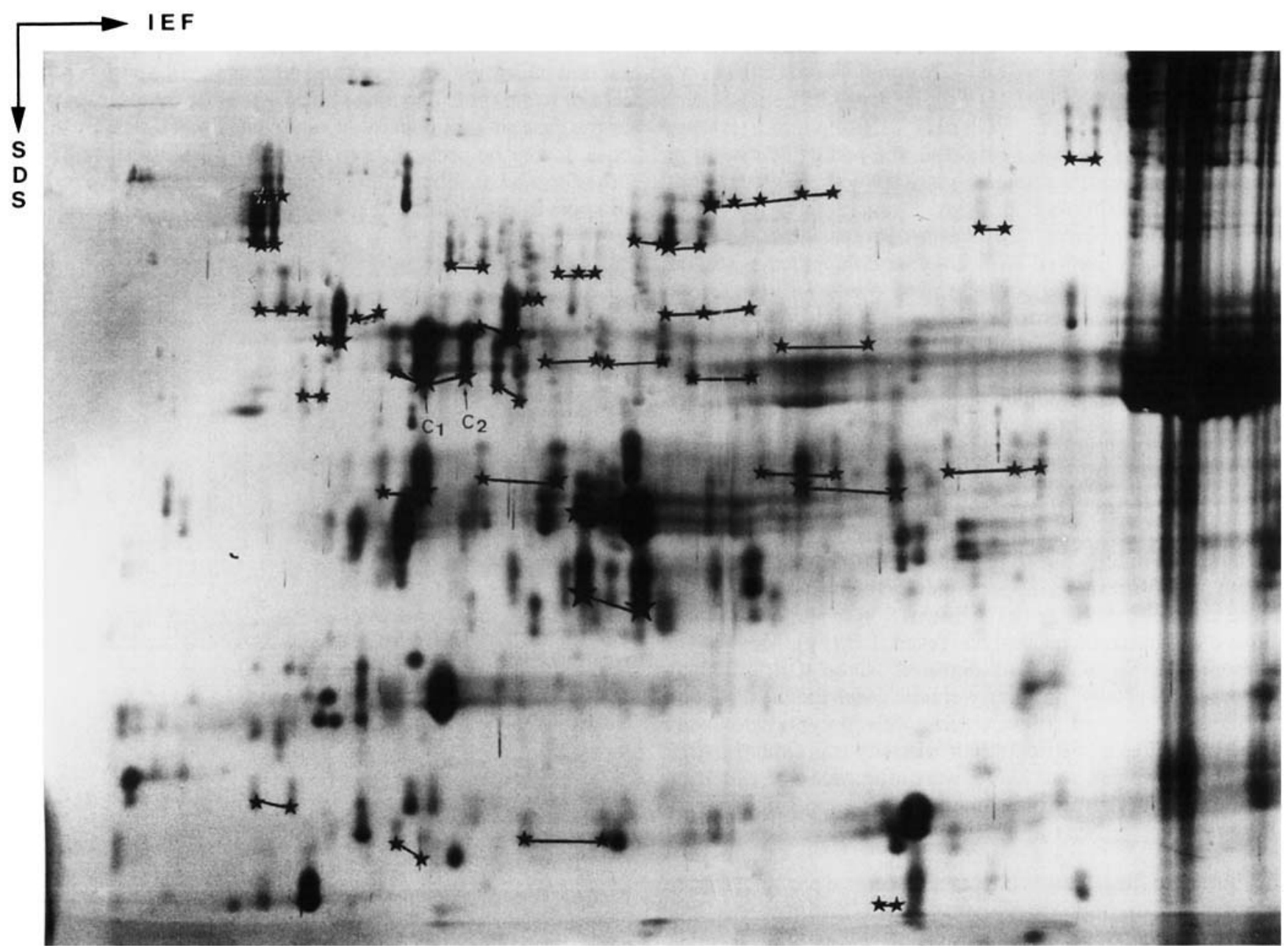

Figure 4. Groups of related polypeptides in "Chinese Spring" leaf proteins. Polypeptides belonging to the same group according to their proteolytic pattern are marked with a star and linked by a solid bar. $\mathrm{C} 1$ and $\mathrm{C} 2$ : two forms of the $\beta$ subunits of the chloroplastic ATP synthase. 


\section{References}

[1] O'Farrell, P. H., J. Biol. Chem. 1975, 250,4007-4021.

[2] Anderson, N. G., Crop Sci. 1985, 25, 667-674.

[3] Cleveland, D. W., Fischer, S. G., Kirschner, M. W. and Laemmli, U. K., J. Biol. Chem. 1977, 252, 1102-1 106.

[4] Giometti, C. S. and Anderson, N. L., J. Biol. Chem. 1981, 256, 11840-11846.

[5] Zhang, J.-S. Giometti, C. S. and Tollaksen, S. L., in:Dunn, M.J.(Ed.), Electrophoresis '86, VCH Verlagsgesellschaft, Weinheim 1986, pp. 621-625.

[6] Damerval, C., de Vienne, D., Zivy, M. and Thiellement, H., Electrophoresis 1986, 7, 52-54.
[7] Bahrman, N. and Thiellement, H., Theor. Appl. Genet. 1987, 74, 218-223.

[8] Anderson, N. L. and Anderson, N. G., Anal. Biochem. 1978, 85, $341-354$.

[9] Granier, F. and de Vienne, D., Anal. Biochem. 1986, 155, 45-50.

[10] Heukeshoven, J. and Dernick, R., Electrophoresis 1985,6, 103-112.

[11] Damerval, C., le Guilloux, M., Blaisonneau, J. and de Vienne, D., Electrophoresis 1987, 8, 158-159.

[12] Zivy, M., Thiellement, H., de Vienne, D. and Hofmann, J.P., Theor. Appl. Genet. 1984, 68, 335-345.

[13] Bahrman, N., Cardin, M.-L., Seguin, M., Zivy, M. and Thiellement, H., Heredity $1988,60,87-90$.

\author{
Colin A. Graham \\ W. H. Irwin McLean \\ Anne E. Hughes \\ Norman C. Nevin
}

\section{Department of Medical Genetics,} The Queen's University of Belfast

\section{Characterization of human skin fibroblast extracellular proteins by two-dimensional polyacrylamide gel electrophoresis}

\begin{abstract}
Human skin fibroblasts secrete over 50 proteins into the culture medium. In this paper these are characterised using two-dimensional polyacrylamide gel electrophoresis and peptide mapping of proteins metabolically labelled in the presence and absence of tunicamycin. Thirty of these proteins have been shown to be $N$-glycosides, 4 are $O$-glycosides and 10 are not glycosylated. Of the major proteins, groups 1-4 have previously been shown to be fibroblast specific. Peptide mapping and tunicamycin treatment has identified that groups 1 and 2 , and 3 and 4 are closely related and that groups 1 and 3 arise by $N$-glycosylation of 2 and 4, respectively. The unglycosylated precursor forms of several other proteins have also been identified. This approach to the analysis of protein secretion provides an abundance of information on many proteins simultaneously and can be used to assess the changes in protein secretion associated with development, and to identify extracellular growth factors and other regulatory proteins.
\end{abstract}

\section{Introduction}

Human skin fibroblasts are commonly used for research into cellular function and to study the molecular basis of many diseases. However, little is known about fibroblast extracellular proteins or the distinction of fibroblasts from different tissues. Many proteins contain non-amino acid components attached to the polypeptide chain. The most common of these are the oligosaccaride units which occur in glycoproteins. These side chains can determine a wide range of biological properties $e . g$. intracellular location; structural and immunological characteristics; and proteolytic susceptibility $[1,2]$. Glycosylation is often necessary for secretion into the extracellular environment and all the proteins in human serum are

Correspondence: Dr. C. A. Graham, Dept. of Medical Genetics, The Queen's University of Belfast, Tower Block floor A, City Hospital, Belfast, N. Ireland BT9 $7 \mathrm{AB}$

\footnotetext{
Abbreviations: ASN, asparagine; DMD, Duchenne muscular dystrophy; DMEM, Dulbecco's modified eagles medium: 2D-PAGE, two-dimensional polyacrylamide gel electrophoresis: FCS, fetal calf serum: GN, $N$-acetyl-D-glucosamine; $\mathbf{M}, \mathbf{D}$-mannose: SDS, sodium dodecyl sulphate: $\mathbf{T}+$ cells, tunicamycin treated cells
}

glycosylated during their biosynthesis with the exception of albumin and some of the lipoproteins [3]. Glycoproteins such as fibronectin, laminin and collagens are important constituents of the extracellular matrices of various cell types and are involved in cell adhesion, differentiation and growth $|4|$.

Glycoproteins can be divided into two broad groups according to the mode of attachment of carbohydrate to protein [5]. In both groups the anomeric carbon atom of the first carbohydrate residue is linked by a condensation reaction to an amino acid in the polypeptide chain. In $O$-glycosides, the attachment site is the hydroxyl group of a serine, threonine or hydroxylysine residue. In $N$-glycosides, more common in mammalian cells, the glycosidic bond is formed with the amido group of an asparagine residue.

$N$-Glycosides share a common carbohydrate precursor core structure:

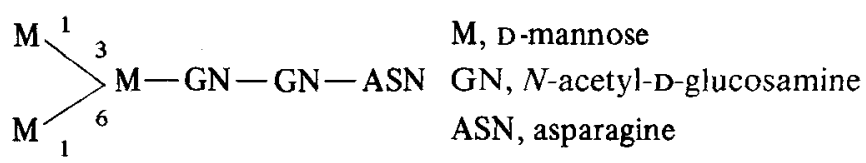

